\title{
Alguns Aspectos da Paisagem em Joaquim Cardozo
}

Sérgio Martagão Gesteira ${ }^{1}$

Resumo: Este artigo tem por objetivo examinar alguns componentes como as sombras, a noite, os ventos e o mar na poesia de Joaquim Cardozo, procurando compreender como o sujeito lírico os articula, a dialética entre o fundo histórico e certa vocação-de-transpor esse enraizamento, os apoios estilísticos de que se serve o poeta e a expressão da presença do mundo que seus poemas manifestam.

Palavras-chave: Joaquim Cardozo. Poesia e paisagem.

\section{Aproximação da paisagem}

A atenção de Joaquim Cardozo quanto à "matéria do mundo grande" resulta no assinalamento de uma experiência de fascínio e nostalgia. Frente a um real plurívoco e movente ("Poliedro de mil faces, fazendo-se, se refazendo"), a palavra poética expressa de modo singular seu acolhimento do advento do mundo. Traduzida a matéria por esse devir proteiforme, o sujeito lírico logo percebe nela, como um atributo de origem, "a angústia do mundo (...) sufocada" (CARDOZO, 1979, p. 137).

O fluxo perpétuo e multívoco com que o sujeito lida se corporifica, na poesia de Cardozo, nas brisas e ventos que acometem o litoral nordestino. Mas, talvez pela aproximação de um real ontologicamente angustiado, tais ares propendem à pintura de uma ambiência de corte nostálgico, afim de certa vocação taciturna do próprio sujeito que a refere.

Como este olhar, em que pese o flagrante vínculo afetivo com as paisagens em que toca, ostenta certo rumo abstratizante, o visível ganha atributos de leveza, que carreiam para os textos do poeta seres como nuvens, brisa, ventos, fumaça, silêncio, asas. A menção a asa(s) parece bem exemplar dessa leveza. Se os pássaros são elementos pouco incidentes na obra, sua apreensão metonímica pela asa aparece no quádruplo de vezes em que há menção ao próprio pássaro. Portanto, em relação a este, o que mobiliza a palavra poética é o que o faz um ser no ar - um ser do ar. Ao pássaro pousado faltaria força para o impulso e voos líricos.

\footnotetext{
${ }^{1}$ Professor Associado de Literatura Brasileira da UFRJ. Doutor em Letras (UFRJ). Organizou e estabeleceu a Obra reunida de Dante Milano (ABL). Autor de $A$ carne da ruina: sobre a representação do excesso em Augusto dos Anjos (Prêmio Mário de Andrade de Ensaio em 2000, Fundação Biblioteca Nacional). E-mail: sergiofmg@gmail.com

2 "Prelúdio e elegia de uma despedida" (CARDOZO, 1979, p.120).

3 "Visão do último trem subindo ao céu", parte VII (CARDOZO, 1979, p.137).
} 
Além dos ventos, ou antes, em conjunção com eles, as águas e a noite também alcançam a hegemonia do olhar de Joaquim Cardozo. A leveza e a tenuidade dessa poesia tendem a afastar a luz mais incisiva, categórica, como a que se desenha no meio-dia a pino da lição cabralina ou, no feliz dizer de Cardozo, naquele "azul em ponto" 4 . Por seu turno, repercutindo enfaticamente a esquivança da luminosidade na paisagem, a noite encontra o espaço adequado para abrir seus matizes para um sujeito lançado no aflito encalço do que se subtrai à imediata decifração. Momento propício, desde logo, para a cogitação do nada e a inserção da morte na obra.

Esse eu angustiado de alguns textos de Cardozo não se volta tanto para si, como o fez e com isso deliciou-se, malgrado o travo de amargura, a alma romântica. No geral, ele pouco contracena consigo mesmo. Nas poucas vezes em que o faz, traduz-se como vivência da errância: "Estou só, sem destino e sem abrigo" em "Mariana" (CARDOZO, 1979, p. 12). Em passagem ulterior, flagrar-se-á como "caminhante solitário no deserto, no noturno" de "As janelas, as escadas, as pontes, as estradas", o que se reitera em pequeno rearranjo pouco em seguida, como "caminhante deserto, no noturno e solitário!" (CARDOZO, p. 180-181).

A nota melancólica igualmente desponta quando o poeta abandona o olhar que se encanta pelos quadros da natureza, como em "Dezembro" - "Profusão de verdes novos/ As cajazeiras todas se enfolharam,/ Sobre os telhados voando as andorinhas" (CARDOZO, 1979, p.14) - e se detém no espaço urbano, momento em que a enunciação desliza a pouco e pouco para os tons desmaiados, em reminiscências de um tempo mágico, de branda melancolia:

Eu vejo os subúrbios tranquilos,

A paz dominical entre os homens e as coisas,

As casas brancas de telhados de biqueira

E fico a pensar e a sentir

Dentro de minha tristeza espiritualizada.

Tenho a suspeita de um talvez feliz,

Vaga incerteza de um prazer antigo,

$\mathrm{Ah}$ ! Desejo de lembrar coisa esquecida

Raras, remotas, imprecisas volúpias de segredo e de saudade. (CARDOZO, 1979, p..15)

Essa espiritualização da tristeza, também por efeito da pluralização dos entes que aí se dão, impede o discurso de resvalar para o tom mais dramático, porquanto dispersa a eventual concentração desse estado em um ser ou fenômeno representativo. A pátina melancolizante não deixa de despontar aqui e ali, atingindo expressão mais incisiva, por exemplo, quando se observam, em "Prelúdio e elegia de uma despedida", o fascínio e a angústia congeniais da inscrição humana na paisagem de uma noite total. É quando se

4“Soneto da vinda” (CARDOZO, 1979, p. 195).

Gláuks: Revista de Letras e Artes - jul./ dez. 2019 - Vol 19, $N^{o}$ 2, ISSN 2318-7131 
delineiam "as curvas de nosso grito", lancinante ressonância da retração da totalidade dos entes à presença do homem, o que só faz percutir "de nós, a ausência e o vazio" (CARDOZO, 1979, p 120.). Ou, no "Soneto somente", em que o advérbio de modo do primeiro terceto circunscreve, em feição severa, a pouca relevância do obrar do próprio eu: "Pois tudo quanto fiz foi superfície/ De inúteis coisas vãs, humanamente" (CARDOZO, 1979, p. 196). Porém o obrar humano, enquanto inscrição na História, não recebe de Cardozo o discurso aficionado, a entronizar as augustas conquistas do homo sapiens. O que convoca o poeta com inegável apelo é antes a consideração do mundo em sua mais vasta presença - o grande cosmo da vida. Por isso o sujeito dos versos de Cardozo, como o dissemos, situa-se de preferência à margem das cenas, a não ser como instância enunciadora inevitavelmente implicada na tradução para a poesia da "matéria do mundo grande".

Face à vastidão desta, a voz poética pode soltar-se e verbalizar toda sorte de conjecturas sobre os quadros que concebe, ainda as mais hipotéticas. Disso resultam sintaxes imaginárias expressivas, sutilmente tocadas pelo humour, como neste passo da "Poesia da presença invisível":

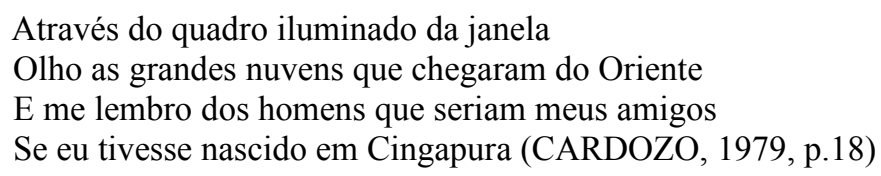

$\mathrm{O}$ à vontade com que Cardozo se acerca de realidades conjecturais fica aí manifesto: as segmentações de espaço e tempo baralham-se, a hipótese encontra o apoio em que possa fluir. Na retina facilmente impressionável do eu lírico, o mais tíbio movimento suscitará imbricações insuspeitadas. O poeta pernambucano, talvez por sua formação matemática ou de calculista de Niemeyer (pensamos aqui no efeito de leveza das obras do ilustre arquiteto) busca facetas mais sutis na paisagem, como se a quisesse de alguma forma considerar sob o ângulo que favorecesse configurações do leve e do sinuoso. Não poucas vezes frequentam essa poesia o termo curva e cognatos. Não que ele se desapegue do enraizamento na experiência entranhadamente sua, histórica, vivencial, do Recife ou de Olinda, com as cajazeiras, os cajueiros, as macaibeiras, as pitangas e os jasmins laranja a pontuarem a cor local. E outras referências concretíssimas, como o cais de Apolo, despontam desde o primeiríssimo poema de Cardozo, "As alvarengas", datado de 1925. O mesmo cais ressurge logo no segundo, "Velhas ruas", enquanto o título do terceiro é "Olinda", e o do quarto, "Tarde no Recife". Há ainda o sabor de lugares como Pirapama, Persinunga, Serinhaém, Apipucos e outros sítios, que acrescentam a esse tempero localista o encanto sonoro tão propício àquela quarta dimensão do

Gláuks: Revista de Letras e Artes - jul./ dez. 2019 - Vol 19, $N^{o} 2$, ISSN 2318-7131 
poema enfatizada por Abrams 5 . Mais para o fim das Poesias completas, encerrando o derradeiro dos, assim designados, sonetossons, surge o poema "Nossa Senhora dos Prazeres", que, malgrado as várias igrejas homônimas no Brasil, indica em itálico no final a localização particularizante, de "Na igreja do Monte Guararapes", não tão distante do centro de Recife.

Apesar de estear-se assim no solo histórico, há em Cardozo, talvez também em herança da dicção simbolista, uma propensão ascensional, de cunho generalizante, em que sobressai a expansão do foco sob a lente lírica. Não é incomum, de igual modo, o olhar do poeta lançar-se, ainda que de forma provisória - porque logo buscando articulações novas -, no diálogo entre o mais abstrato e o concreto.

Não procede buscarmos aqui a proveniência longínqua desse estilo de captura do visível em direção ao etéreo, típico de uma imaginação expansiva. De hábito, senão de índole, o romântico, por exemplo, amou demasiadamente os contrastes, sobretudo o que ostentasse uma impactante subitaneidade, a favorecer a ênfase retórica, como Castro Alves em suas passagens mais interjetivas, acionadas por pressão do tempo histórico. Ou, talvez à guisa de cotejo, a deriva para o outro lado dessa pendulação, no mais adagial do antológico poema, também romântico, com o seu "Ma sedendo e mirando, interminati/ spazi di lá di quella, e sovrumani/ silenzi, e profondissima quiete" de "l'Infinito" de Leopardi, com que o espírito romântico terá buscado escutar o coração da eternidade e o silêncio do devir. Mas essa harmônica promesse de bonheur, tal como Stendhal definiu o Belo ${ }^{7}$, comparece apenas de modo transversal à poesia de Cardozo, pois nela o agenciamento paciente da matéria não se vê subsumido à hegemonia de um espaço dispersivo, subtraído ao mais pulsátil. O devaneio que sustenta e enforma a poética cardoziana se encontra, muitas vezes, surpreendido por inesperadas e bruscas segmentações, sob a ação de um fascínio a discernir, na totalidade physica do mundo, as forças aí arregimentadas e atuantes, tudo sob o rigor da formalização atenta, mas rigor que mira também o vigor com que a matéria comparece com seu peso próprio, sua presença multifária, seus ruídos, seus espasmos. Não raro, tais forças, enfatizando a turbulência do mundo, são o sinal agônico de um estado de desamparo da matéria consentâneo ao do eu lírico, o que se refratará em marcas do fluxo incessante dos seres, um dos quais, os ventos, mais ou menos brandos, mais ou menos intempestivos, se tornam protagonistas dos sítios por onde passam.

\footnotetext{
${ }^{5}$ ABRAMS, M.H. (2012). Abrams se refere ao potencial enriquecimento do poema por tudo aquilo que os elementos fônicos e outros recursos da leitura oral podem acrescentar ao texto, pela interação criativa com o significado e a disposição $($ mood $)$ deste.

${ }^{6}$ LEOPARDI (1974, p. 41). "Mas sentado e mirando, intermináveis / espaços além dela, e sobre-humanos / silêncios, e profundíssima quietude" (traduzimos).

7 "La beauté n'est que la promesse du bonheur." (STENDHAL, 1857, p. 34). "A beleza não é senão a promessa de felicidade. (traduzimos).
}

Gláuks: Revista de Letras e Artes - jul./ dez. 2019 - Vol 19, $N^{o}$ 2, ISSN 2318-7131 


\section{A paisagem, mais de perto}

A maneira como Joaquim Cardozo se abeira do real visível explica o generoso acolhimento das imagens de trânsito, donde a altíssima incidência de brisas, ventos e ventanias nos poemas. Os ventos ganham específica textura quando se traduzem por “(...) finos cabelos/ Na luz (CARDOZO, 1979, p. 43); ou quando com eles se enlaçam, como em "Elegia para Benedito Monteiro": "Nos teus cabelos há vestígios das indomáveis ventanias" (CARDOZO, 1979, p. 20); ou, ainda, em "O capataz de Salema", de "Fragmentos de uma conjectura dramática", na inspirada imagem de "Luzia, dos teus cabelos/ Farei os ventos da noite," (CARDOZO, 1979, p. 83).

Frequentemente, pela circunscrição geográfica desses ares no Recife, em Olinda e em outras plagas do litoral nordestino, trata-se de ventos sobretudo marinhos, como em "Inverno": "Ventos, velas fantasmas que vêm perdidas do alto mar." (CARDOZO, 1979, p. 8); ou "O vento vinha do mar sobre os sobrados antigos/ Do velho Recife:" (CARDOZO, 1979, p.183). Mas não advém apenas desse fundo histórico e mais personalizado o prestígio deles na obra do poeta. Por si mesmos, eles são muito adequados a modular afetivamente os elementos da paisagem. No mundo incansavelmente posto a mover-se (não fossem os ventos antes de tudo o que passa), a realidade encontrará neles, desde a mais tênue brisa aos ares mais impetuosos, a imagem propícia a figurar um mundo enriquecido por ritmos plurais.

A manifestação deles não se limita apenas ao mais trivial registro no corpo do sujeito poético, como em "Ouço o vento do mar na telha-vã" do segundo dos "Três sonetos positivos" (CARDOZO, 1979, p. 61), mas igualmente no corpo do próprio vento, o que aumenta a informação estética da incidência: "A chuva cai, alaga o chão, encharca os ventos" de "Inverno" (CARDOZO, 1979, p. 8); ou nesta imagem, já de vivo corte surrealista: "Ao passo que, em falsete, a voz fina do vento/ Faz rir os cartazes." de "Recife morto" (CARDOZO, 1979, p. 17) ; ou neste "E pelos pés difusos do vento é que marcho/ Na bruma das madrugadas..." de "Canto do homem marcado" (CARDOZO, 1979, p. 78).

Não poucas vezes as agruras, agora já existenciais, do vento ocupam o proscênio, exprimindo com insistência o compadecimento da poesia de Cardozo quanto aos seres que, por sua própria natureza, se apresentam erradios, em quadros que lhes ressaltam o desamparo inato ou circunstancial. Não é raro o repontar dessas cenas de fragilização e penúria. Citaremos algumas, a começar pelas do já referido "Inverno", de 1925: "Pobres ventos sem trabalho,/ Expulsos dos moinhos, dos navios,/ Desembarcados no primeiro porto,"; e, prosseguindo nessa convincente personificação dos ventos desgarrados: "E que vão pelas ruas

Gláuks: Revista de Letras e Artes - jul./ dez. 2019 - Vol 19, $N^{o}$ 2, ISSN 2318-7131 
vazias/ Batendo às portas num clamor de rajada,/ De lamento e revolta. (CARDOZO, 1979, p. 8). Apresentam-se também como ventos "feridos", "irados" em "Figuras do vento" (CARDOZO, 1979, p. 43). Ou nesta caracterização da primeira estrofe de "Ventos, puídos ventos" : "Gastos no seu tecido,/ Trapos que se penduram/ Moles da verde palha." (CARDOZO, 1979, p. 54).

É oportuno lembrar o valor simbólico daquele "vento sombrio" que fecha de modo lúgubre o Trivium, no "Cântico da Serra dos Órgãos”, verdadeiro libelo contra essas afobadiças criaturas, os homens, “Correndo nas planícies do chão e do ar/ Em suas máquinas ingênuas;/ Apressados, sôfregos, apressados. ¡Como apressados!” Esse sombrio vento fecha ao modo de um resíduo póstumo e pesadelar a aniquilação definitiva do planeta e do bicho da terra tão pequeno, na catástrofe cósmica em que os humanos, supostamente superiores no conjunto da natureza, "Da vida natural se desfazendo,/ Se tornarão bonecos, robôs, títeres, fantoches..." (CARDOZO, 1979, p. 149), a cena completando-se soturna: "E muito antes que a Terra deles prescinda,/ Que a Terra recuse as suas presenças,/ Os homens estarão mortos suicidas;" (CARDOZO, 1979, p. 153). Como se vê, muito desse discurso tem sua atualidade.

Mas, quanto aos ventos, uma circunstância lhes justifica a presença além dessa intensiva modulação lírico-afetiva dos quadros precedentes: a de atribuir vivacidade ao que, de outro modo, seria o império do amorfo, do esvaecido. Encena-o magistralmente o "Jardim de terra e vento", que opõe a um prévio cenário desvitalizado a súbita irrupção da força arborescente do vento: “(...) que, às vezes, floresce em vela branca,/ Frutifica em asas e em gotas d'água;", resultando na exortação de "Vinde colher seus frutos, suas bagas maduras!" (CARDOZO, 1979, p. 173). O vigor germinativo dos ventos contrasta com o status quo ante do quadro natural:

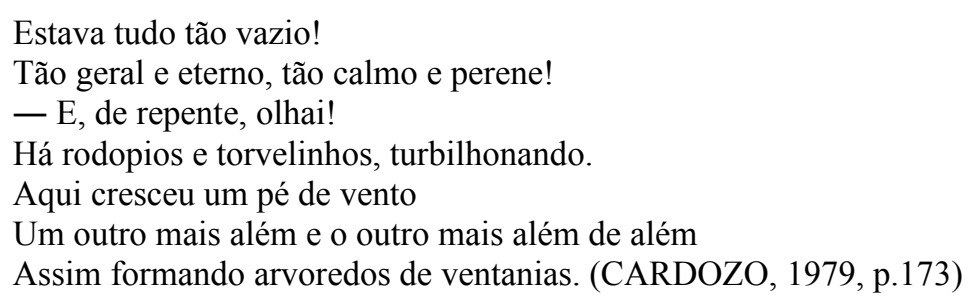

Além dos ventos, outra das matrizes diletas, proveniente do enraizamento da voz poética no espaço nordestino, e que também responde pelas imagens de movimento são as águas, não tanto as empoçadas, confinadas em ambientes lacustres, mas as agitadiças, como as do mar aberto, ou as que se precipitam, como as da chuva, ou correm, como as dos rios.

Em confluência com o mar, e ainda como desnorteio dos ventos provenientes das paisagens marinhas, ou com estas urdindo seu mútuo pertencimento, lemos em "Inverno" a

Gláuks: Revista de Letras e Artes - jul./ dez. 2019 - Vol 19, No 2, ISSN 2318-7131 
penúria e a agressividade dos exclus, nestas "Velas fantasmas que vêm perdidas do alto mar." (CARDOZO, 1979, p. 8) ou, nos mencionados "Ventos, puídos ventos", vistos como "Tristezas do alto-mar,/ Murmúrio gotejante"(CARDOZO, 1979, p. 54); ou na derradeira sextilha do mesmo poema, os "Ventos, naves de vento,/ Cargueiros de amarugens;", com essas amarugens, que significam amargura, tristeza, podendo aqui associar-se, além de ao mar, e por liames imaginários e fônicos, a amar e a marujos, nesses cargueiros que colhem "os sons aflitos" de um "afrontado mar", e se tornam a "voz dolente", que o poeta ouve cantar, no mesmo poema.

Afrontado mar... De fato, em que pese aqui e ali a celebração da solaridade e dos claros painéis marinhos na obra do poeta pernambucano, tal como o ressaltam versos como os do tão flagrantemente intitulado "O meu canto é de sol!", até naquilo que o faz iniciar-se e fechar-se com a mesma asserção efusiva do título, além da feliz escolha de uma ave de tão fulgurante exuberância quanto o pavão, símile dos coloridos do mar nordestino:

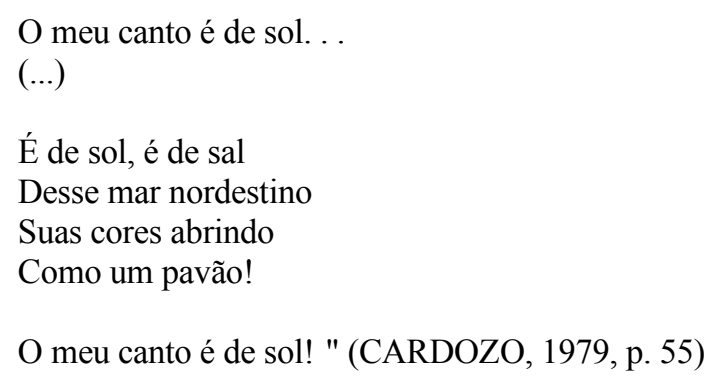

; apesar, portanto, deles, dessa dicção calorosa e colorida, o mar em Cardozo costuma aproximar-se do enquadramento noturno, também em sua tradução emotiva. Como em “(Eu) Que vi paisagens do céu erguidas sobre a noite do mais alto e puro mar," do "Poema dedicado a Maria Luiza" (CARDOZO, 1979, p. 30); e em "Do Recife se desce para o mar,/ Para a noite do mar." de "Nesse mar" (CARDOZO, 1979, p. 56).

É que o mar, assim como a noite, é agenciador de um tema muito caro à obra de Cardozo: a morte e, de modo conexo, a memória amorosa, desde cenas de recordação tocadas de delicadeza, como em "Venho para uma estação de águas nos teus olhos;/ Ouves? É o rumor da noite que vem do mar./ Meu amor.", de "Canção" (Cardozo, 1979, p.15).; ou o mar e suas ondas, compondo-se também no discurso amoroso, como nesta, a justíssimo título, antológica "Canção elegíaca", a repercutir, na metamorfose mágica dos seres e na retrogradação das águas, a cogitação da futura morte da amada:

\footnotetext{
Ondas do mar — traiçoeiras -

A mim virão, de tão mansas,

Lamber os dedos da mão;

Serenas e comovidas
}

Gláuks: Revista de Letras e Artes - jul./ dez. 2019 - Vol 19, $N^{o}$ 2, ISSN 2318-7131 
; até as ondas, já não mansas, mas arremetidas, impulsivas, evocando as lutas da invasão e a permanência holandesas em Pernambuco, como na passagem, vincada de um assomo alucinatório a irromper em frases nominais nos seguintes versos, em acumulação cinética que secciona ex abrupto o curso do enunciado, agora historicamente encandecido:

Vultos brancos de aparições estranhas,

Vindos do mar, do céu... Sonhos! Evocações!

A invasão! Caravelas no horizonte!

Holandeses! Vryburg!

Motins. Procissões. Ruído de soldado em marcha. (CARDOZO, 1979, p.17)

Quando vinculado à condição mortal e suas circunstâncias, o mar aparece, além de aliado à noite e aos ventos, de igual forma às ondas e às chuvas que lhe acentuam o perfil fremente. Ilustra a contundência que perpassa essa figuração tempestuosa a "Elegia para os que ficaram na sombra do mar", de Poemas, de 1947, mas elaborado, como o texto o indica, na concreta Praia do Farol, em Olinda, em 1937, o que lhe espessa o efeito de real:

\author{
Noite avançada, muita chuva no mar, \\ Uivos, latidos de ventos soltos, desesperados, \\ Vozes rezando de naufragados. \\ Ouço que estão batendo à minha porta. \\ São aqueles que vivem na escuridão do mar \\ São aqueles que moram com a noite no fundo do mar \\ E com a noite e com a chuva estão batendo à minha porta: \\ São piratas, são guerreiros, \\ São soldados que voltavam das Índias, \\ São frades que iam para o Japão, \\ São soldados, são guerreiros, \\ São marinheiros. \\ São eles que passam levados pelo vento \\ Ao longo dos mocambos dos pescadores; \\ São eles que giram como grandes e estranhas mariposas \\ Em torno do farol. \\ Sim, são eles que vão a estas horas, voando \\ Nas asas da chuva e da noite e das ondas do mar. \\ São soldados, são guerreiros \\ São marinheiros. (CARDOZO, 1979, p. 27-28)
}

Notem-se os traços intensificadores do desconcerto dos elementos integrantes do quadro: a hora tardia, a manifestação vocal que animaliza o vento e expõe seu franco desnorteio ("uivos", "latidos"), a ecoar dramaticamente nos fonemas plosivos aliterantes e na

Gláuks: Revista de Letras e Artes - jul./ dez. 2019 - Vol 19, $N^{o} 2$, ISSN 2318-7131 
fricativa de "latidos de ventos soltos", bem como nos esses da intensa sibilação; e o reverberar deles, ventos, no "estão batendo" do monóstico seguinte, por sua vez reduplicando o gerúndio de "vozes rezando", o que resulta no prolongamento do desconcerto pelo recurso da presentificação. Entretanto, para que o traço sibilante da consoante não vozeada /s/ dos entes pluralizados não comprometa a crispação geral da cena, suavizando-a, o terceto se apoia, desde o início, nas constritivas de vocábulos como chuva, uivos e "ventos desesperados", e mesmo nessas "vozes rezando", logo referidas como "de naufragados", com a abundância dos róticos que, a partir desse terceto inicial, se espraiam na designação dos personagens permanecidos à sombra do mar — os guerreiros, frades, piratas e marinheiros, no fecho da oitava.

Observe-se, ainda, o recurso anafórico de "São", a exprimir a insistência dos que se foram para a sombra das águas e agora emergem para os ares e as luzes do farol, ressuscitando a memória das navegações que singraram os grandes mares entre o crepúsculo do Medievo e a aurora da Renascença (no poema, as Índias, o Japão, os soldados, os clérigos) e agora volteiam sobre os mocambos como "grandes e estranhas mariposas". Há nada menos que onze ocorrências de versos iniciados assim no conjunto desses dezessete, sem contar o "Sim, são eles que vão a estas horas, voando" em que novamente as fricativas realçam a figuração da mobilidade.

Mas nem sempre o mar ostenta essa face dramática e tempestuosa quando se alia à morte. E assim acontece quando traz para a poesia a evocação de uma outra noite, a qual, em Joaquim Cardozo, se inelutável e lutuosamente carreia logo a rememoração do mar, propicia à dolência de algumas das palavras do segundo dos "Três sonetos positivos" a seguir - como as "imprecisas mágoas", o "ferido corpo" - um final apaziguamento por efeito do tom final, encantatório:

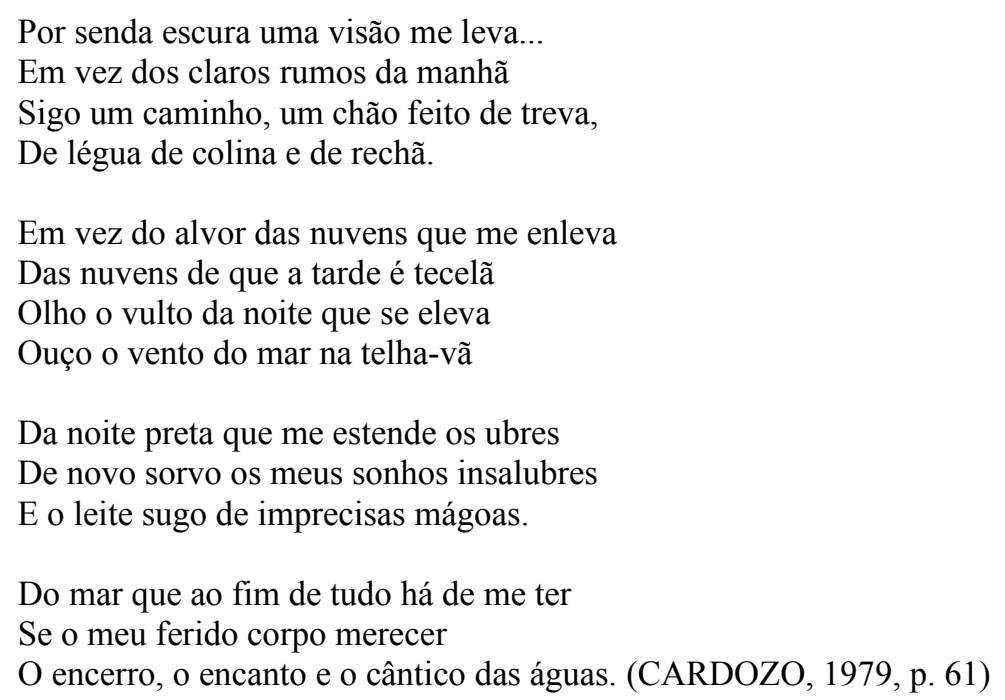


O soneto se elabora com uniformidade quanto aos que nele atuam. Os quartetos opõem, com reconhecível simetria entre os dois versos iniciais e os dois finais de cada um deles, o dia e a tarde, que a voz da enunciação afasta, e a noite, que ela acolhe. O primeiro par de versos do quarteto inicial concentra a oposição básica "senda escura" x "claros rumos da manhã", enquanto o segundo par reforça o peso da escuridão da noite no caminho "de légua de colina e de rechã". Os fonemas laterais em "colina" e "légua", recaindo nas sílabas tônicas dessas palavras, emprestam-lhes a musicalidade capaz de sugerir um rítmico percorrer dessas terras altas em que eu lírico se põe, ou a que o leva sua visão.

A segunda estrofe subdivide-se, com nitidez, igualmente em dois pares, o primeiro referente a alvor, ainda que o da tarde (prenúncio, talvez, do anoitecer que se imporá); e o segundo, contrastando o olhar e o ouvir, complementar e respectivamente referidos a "o vulto da noite" e "o vento do mar", sintagmas em certa medida paralelísticos, seja pela estrutura sintática (verbo-objeto direto-adjunto adnominal), seja pela unidade rítmica, com a marcação das sílabas fortes nas primeira e terceira sílabas de seus respectivos versos, até, portanto, alcançarem o icto da sexta sílaba, a abrir a cesura ao decassílabo heroico: "O/lho o / vul/to /da /noi/te /que/ se e/le/va / $\mathrm{Ou} / \mathrm{ço} \mathrm{o} / v e n / \mathrm{to} / \mathrm{do} / \mathrm{mar} / \mathrm{na} / \mathrm{te} / \mathrm{lha} /-v \tilde{a} "$.

Até aqui, em termos de imagem, estamos situados, pois, em um espaço alto, como o referido altiplano ("rechã") e a colina, realçados por termos como nuvens e o emprego do verbo elevar. Os tercetos, por sua vez, se dividirão de maneira consequente e complementar: a noite ocupará o primeiro deles, e o mar, o segundo. O aleitamento propiciado pelos úberes da "noite preta" (possível cruzamento com a imagem de uma ama de leite, ou de uma mãe preta) ganha sua restrição, possivelmente moral, na adjetivação aplicada a sonhos, "insalubres", e em seguida estende sua negatividade mediante as "imprecisas mágoas" do verso subsequente. O soneto, a esta altura, adquire traços que adensam certos termos indiciais das quadras precedentes, como a "senda escura", o "chão feito de trevas", o "vulto da noite que se eleva" (em que a oração adjetiva pode referir-se seja ao vulto da noite ou apenas à noite, mas ambas alternativas confluindo para a mesma caracterização).

Consideremos agora o último terceto. Ele abandona os sítios de altitude para baixar ao mar, e nesse descer também simbólico reitera-se a marca dolorosa no sujeito - aqui seu corpo, dito ferido. Neste passo - "Do mar que ao fim de tudo há de me ter" — o eu, que já sorvera o leite dos úberes da noite, agora refere o seu, por assim dizer, túmulo marinho, matizado pelas graças, não propriamente do mar, da austeridade do mar, tantas vezes tormentoso e atormentado; mas de suas mais femininas, sedutoras e/ou maternais águas cantantes, a enlevarem o sujeito lírico ao figurar sua hora derradeira.

Gláuks: Revista de Letras e Artes - jul./ dez. 2019 - Vol 19, No 2, ISSN 2318-7131 


\section{Deixando a paisagem}

Tanto o modo de aproximar-se quanto o de distanciar-se das terras que aparecem na poesia de Joaquim Cardozo se assinala também pela expressão do longínquo como estilo da enunciação. Trata-se do modo de olhar que contempla, na dupla acepção usual do verbo, a paisagem sob a ótica do predominantemente vago, ensejando uma estética do tênue.

Nesse sentido, a consideração do fluxo das coisas prefere um tempo pouco aquecido. Se o eu lírico se vê atraído pelo movimento a indicar uma vitalidade que o fascina quase sempre, por outro lado ele não se mostra seduzido, como já pontuamos, pelos quadros de intensa movimentação, tal como os típicos dos centros citadinos. Em mais de um poema, já desde 1925, o poeta canta a cidade em que nasceu e em que desejaria morrer ("Essa terra do meu nascer/(...)/ Que seja, e seja, e seja, no fim, no sempre,/ A minha terra de morrer.”, de “Recife - várzea: último retorno', CARDOZO, 1979, p. 157); mas na descrição urbana reiteram-se os elementos que remetem ao tempo antigo e ao presente moderno sem apelo àquela secular cisão em que tanto se comprazia a crítica ferrenha à cidade e o louvor desmedido à paz dos campos, de que há em nossa poesia exemplos à farta - basta lembrar o Fagundes Varela de "Em viagem" ou de "A cidade", ou o Bilac de "New York", opondo a metrópole americana à graça mais atemporal de uma pacata Lutécia-Paris ${ }^{8}$ —, pois em Cardozo os termos oponentes não tendem tanto a recorrer às tintas fortes. Na dinâmica Recife do século XX, por exemplo, observa-se em Cardozo uma atmosfera menos glamorosa, sem dúvida, se contrastada ao passado da cidade, ao lado antigo e algo mágico das reminiscências históricas. Mas as polarizações não se mostram tão extremadas:

\footnotetext{
Tanta gente apressada, tanta mulher bonita;

A tagarelice dos bondes e dos automóveis.

Um camelô gritando: - alerta!

Algazarra. Seis horas. Os sinos.

Recife romântico dos crepúsculos das pontes,

Dos longos crepúsculos que assistiram à passagem dos fidalgos holandeses,

Que assistem agora ao movimento das ruas tumultuosas,

Que assistirão mais tarde à passagem dos aviões para as costas do Pacífico;

Recife romântico dos crepúsculos das pontes

E da beleza católica do rio. ("Tarde no Recife", CARDOZO, 1979, p. 7)
}

Os aportes da modernidade urbana, de que se flagram a algazarra, o "alerta!" do camelô, as ruas tumultuosas, os bondes e os automóveis tagarelas, os aviões ${ }^{9}$, tudo parece contrastar com o

\footnotetext{
${ }^{8}$ Soneto pertencente à obra Tarde, de 1919. In: BILAC, 1985, p. 204.

9 Cardozo não exibe entusiasmo por essas máquinas e, confrontando-as aos pássaros, destaca a leveza destes como está em "Canto da Serra dos Órgãos", onde lemos que os homens "procuraram, imitando as aves,/
}

Gláuks: Revista de Letras e Artes - jul./ dez. 2019 - Vol 19, $N^{o}$ 2, ISSN 2318-7131 
"Recife romântico dos crepúsculos", que traz de volta a memória, não a mais turbulenta, de batalhas, mas a dos "fidalgos holandeses", em crepúsculos, aliás, ditos "longos", o que vale frisar aqui. Já em "Recife morto", e depois de versos tão expressivos como "As janelas das velhas casas negras,/ Bocas abertas desdentadas, dizem versos/ Para a mudez imbecil dos espaços imóveis." (CARDOZO, 1979, p. 17), a malha viária da capital pernambucana enseja o belo contraste entre a imagem da dor do corpo crucificado da grande pólis e as mãos cariciosas da madrugada:

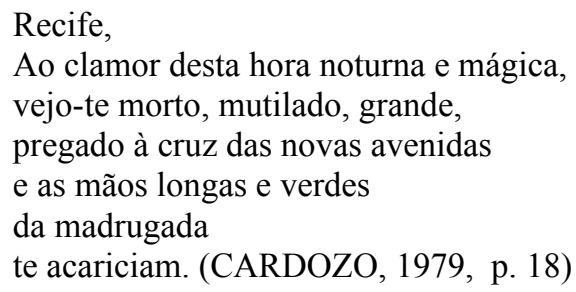

Esse "longas" aplicado a verdes mãos, como os "longos crepúsculos" de "Tarde no Recife", são bem reveladores de uma peculiar maneira de o eu lírico focar o visível. Talvez haja nisso algo da tendência romântica de requisitar a distância em proveito da idealização, como em "A nudez longínqua e de pérola/ Do teu corpo de nuvem" do "Poema do amor sem exagero" (CARDOZO, 1979, p. 26). De regra, porém, o alongar, bem como o longo e o longínquo são antes um modo de considerar o espaço sob a ótica que privilegia a amplitude na visão do conjunto, ou a distância menos submetida à pressão do detalhe; ou a opção por um aproximar-se em ritmo lento, a colher as linhas sinuosas do objeto: “Desta humilde trapeira sem flores, sem poesia,/ Alongo a vista sobre as águas,/ Sobre os telhados.", de "Recife de outubro"(CARDOZO, 1979, p. 13); e, contrastando com um "Volume a se conter bem perto", este "Espaço, a se expandir tão longe/ Mar aberto a proa de navio,/ Trens coleando rampas nos montes..." (CARDOZO, 1979, p. 103).

O longe, o longínquo, o longo não estão apenas a serviço da caracterização denotativa costumeira da distância e do comprimento. Sustentam a referência às origens, que, na sensibilidade ecológica de Cardozo, já em 1925, em “Alvarengas”, os implicavam como vinculados à exploração econômica da mata de onde provinha o madeirame das alvarengas, as quais "Vêm de longe, dos campos saqueados/ Onde é tenaz a luta entre o Homem e a Terra,”; ou, retratando-as sob tintas expressionistas, em "Trazendo, nos bojos negros,/ Para a cidade,/ A ignota riqueza que o solo vencido abandona,", de modo que, "lentas", "Vão seguindo, negras, jogando, cansadas;/ E seguindo-as também em curvas n'água propagadas,/ A dor da Terra, o clamor das raízes".

Conquistar um voo", resultando em que "Apenas conseguiram a fuga da catástrofe/ Nunca o voo legítimo do pássaro/ Que com ele nasceu, (...)”(CARDOZO, 1979, p.152)

Gláuks: Revista de Letras e Artes - jul./ dez. 2019 - Vol 19, No 2, ISSN 2318-7131 
(CARDOZO, 1979, p. 3, 4). Em outro passo, potenciadas pelo discurso poético da "Terra do mangue", menciona-se a origem longínqua das vagas oceânicas, na prosopopeia que lhes flagra, igualmente, o sintomático cansaço: “As ondas do mar que vieram seguindo a noite/ Desde lá detrás dos horizontes/ Estendem-se cansadas na areia" (CARDOZO, 1979, p. 28).

Quando o longe se põe ao habitual serviço da figuração do tempo, ele propende a recobrar passados míticos. Ou mágicos, no lirismo de alto quilate de uma estrofe como esta, de "Canção elegíaca":

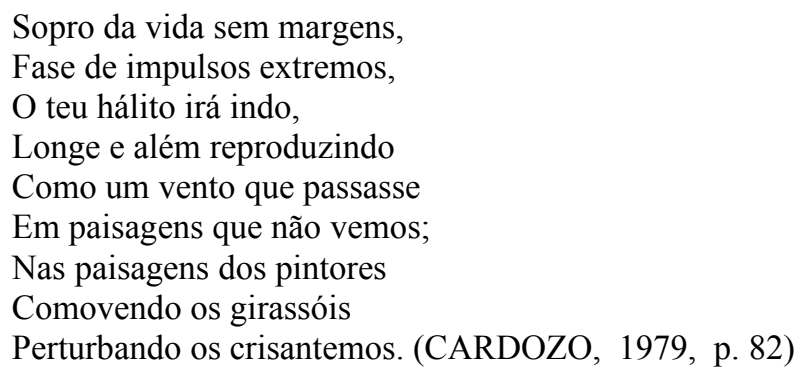

Ou na convergência mítico-sonhosa, quando o longe traz ao poema a memória dos tempos d'antanho, em "Olinda": "E neste mar distante e verde, neste mar/ Numeroso e longo/ Ainda vejo as caravelas ...” (CARDOZO, 1979, p. 5)

Mencionamos termos como longo, longe, longínquo, alongar, que ocorrem em profusão na poesia de Joaquim Cardozo. Eles se situam em um campo semântico afim da expressão da calma e do cíclico (“Ciclo da matéria frágil, severa e obstinada!", CARDOZO, 1979, p.10) com que o poeta observa certa dinâmica da natureza, contrastando-a aos “prodígios" irrequietos da civilização da técnica ${ }^{10}$. Daí que, por dissonância, algo do reino do longínquo, do inatual, proveniente da herança mítica de um illo tempore, emerge com frequência no presente de cenas e de vultos históricos, o que, em "Recife de outubro", enseja um convincente amálgama entre a imagem de umas torres agudas e o passado da cidade. Aí os versos, por pressão metonímica e alastramento visionário, aproveitam o percuciente aspecto da torre para trazer à baila, em pinceladas vívidas e trágicas, a evocação de batalhas do fundo histórico, convertendo-as em um forte memento mori:

Toda a cidade, eu vejo, está transfigurada

É um campo desolado, negro, enorme,

Onde rasteja ainda

O último rumor de uma batalha;

E a massa negra dos edificios,

\footnotetext{
${ }^{10}$ Já fizemos referência aos pássaros, contrastados ao esforço humano de voar, já que eles têm o voo, como diz a bela imagem do poeta, "guardado dentro das asas". O mesmo raciocínio se aplica ao contraste entre os peixes e os homens, que apresentam um "- Flutuar vacilante e postiço - " ao contrário dos peixes, destacando, quanto a estes, "a imanência que têm, dos meios fluentes/(...) Navegando o seu dormir". (CARDOZO, 1979, p. 152-153).
} 
As torres agudas recortando o azul sombrio,

Cadáveres revoltos, remexidos,

Com os braços mutilados

Erguidos para o céu. (CARDOZO, 1979, p. 13-14)

Excetuando-se esses instantes mais tensionais, a emprestar celeridade e fraturação ao enunciado da densa e instigante "Visão do último trem subindo ao céu", o eu lírico prefere atentar para o real enquanto este lhe oferece perspectivas de colher a mobilidade do visível e, dentro desta, a presença do tênue, captado em delicadas sinuosidades, que a abordagem do terreno explorará em gestos longos, lentos, abarcando áreas e tempos longínquos, às vezes voltando-se ao plangente (pense-se na mais de uma quinzena de alusões a sinos na obra), tudo favorecendo uma estética do império transhistórico do Tempo sob o decurso finito, escalonado, do tempo. Há algo de visionário nesse modo de atentar na paisagem. E, no cerne dessa leveza, ou no trânsito em que ela aflora, há o que a promove à visibilidade: a luz.

Não resta dúvida de que o mundo de Joaquim Cardozo banha-se de bastante luz. Assim o convida a terra nordestina, com seus coqueiros eloquentes, suas praias claras, seu sol decidido. Já reproduzimos aqui "O meu canto é de sol”; mas vários outros há em que o sol figura, soberano. Entretanto, ocorrências como "Que saudades do sol. Do mar de sol.", de "Canção" (CARDOZO, 1979, p.15), com a ênfase fulgurante, não é o que predomina nos textos do poeta. Nestes, o astro-rei governa as terras em que reina, mas não se entroniza como o faz em João Cabral de Melo Neto. Porque são as sombras que impõem o seu império.

As sombras respondem muito pelo que dota essa lírica de uma pátina nostálgica, a circular sem vestígios da ênfase traumática com que a mesma sombra - naturalmente tão outra - monologa, por exemplo, na convulsiva obra de Augusto dos Anjos. Por outro lado, em uma poesia, como a de Cardozo, caracterizada pela atenção à mobilidade flexuosa, as sombras esmaecem um pouco a demarcação da territorialidade geral, subtraindo da paisagem os marcos que a confinam à prisão tópica. No mundo de Joaquim Cardozo os seres se mostram receptivos à fluência, a qual, junto ao ensombrecer-se do mundo, propicia sintaxes novas.

Dissemos acima que há bastante luz na obra de Cardozo. Mais pertinente seria se tivéssemos dito: há luz bastante na obra - luz que baste. Pois a noite é por excelência a grande companheira da experiência lírica da enunciação. A noite, de um lado; os ventos e o mar, de outro, eis a tríade nuclear da paisagem em Joaquim Cardozo. São termos rigorosamente hegemônicos, e não apenas em prevalência quantitativa. Valem por seu peso relativo e simbólico, pelo que descerram com referência ao ser do mundo e ao ser nele. Metáfora da vacância, do absconso, do silêncio e da morte, ou da emergência de um real

Gláuks: Revista de Letras e Artes - jul./ dez. 2019 - Vol 19, $N^{o} 2$, ISSN 2318-7131 
sobrante a toda designação, elemento de desnorteio e errância do sentido, clausura, esquivança do ser. Esse defrontar-se com a radicalidade do puro Haver enseja a experiência da angústia e em "Prelúdio e elegia de uma despedida" se pode ouvir a queixa funda:

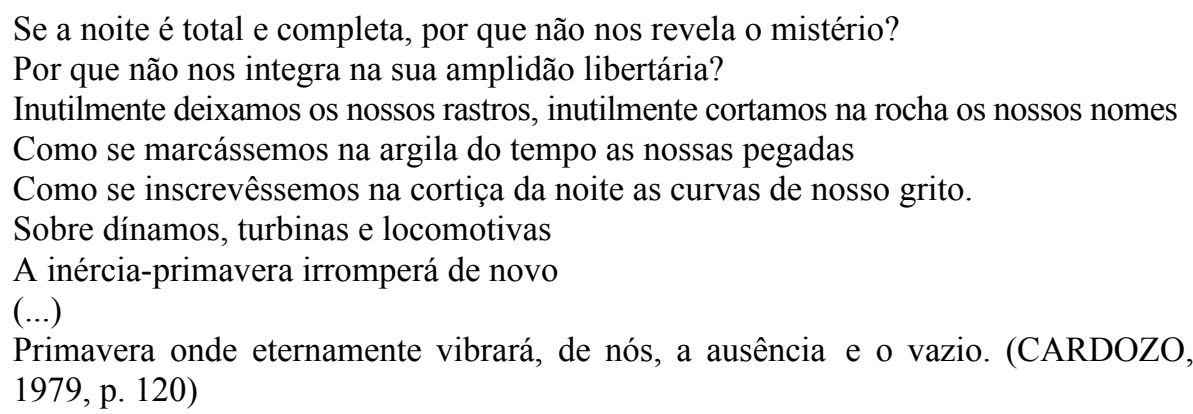

Pouco em seguida, a tentativa de significar o choro noturno que o eu lírico ouvira:

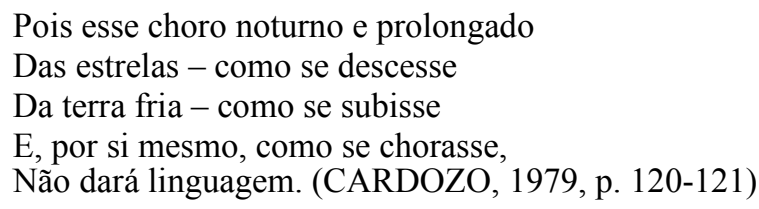

Ou ainda, o radical assinalamento da noturnidade em outro passo do mesmo poema:

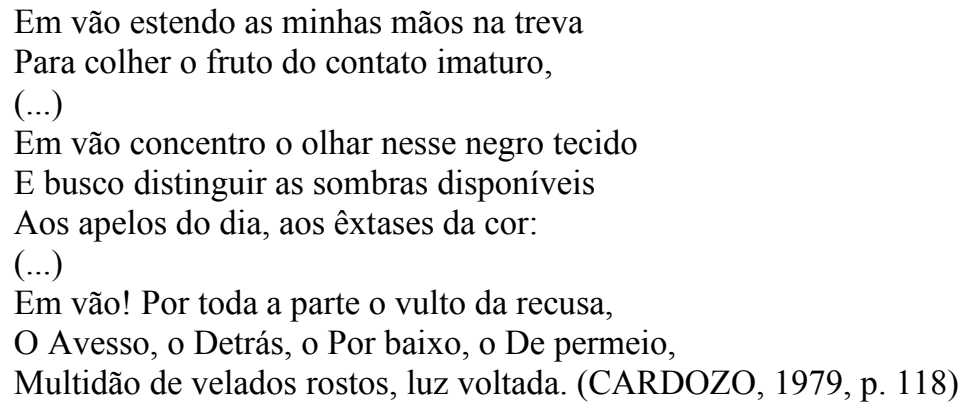

A noite é significativamente referida como "luz voltada", portanto, ensimesmamento sem frinchas, opacificação do em-si nesses rostos encobertos, designações tão expressivas como as que se encadeiam nessa tópica do incontornável: “o Avesso, o Detrás, o Por baixo, o De permeio" - acenos do abissal. O retraimento da noite é um oferecer-se ao pronunciamento da poesia, o que, se leva ao exílio humano do inominável, à carne viva da Presença, ata-se à hipótese de percurso em meio ao obnubilado, ao abscôndito. É a força da predicação poética: “O "real” se torna presente para nós da e pela predicação, assim como é presente no momento da e pela percepção. (...) Não só pela percepção, mas também pela predicação, nós nos conjugamos ao mundo.” (COQUET, 2013, p. 84).

Por isso, o império da noite e suas miragens não é, em Cardozo, o discurso do niilismo. Sua lírica parece esposar certa inquietação contra a dominância imperial da luz que se lê no 
Novalis impaciente contra o dia que insiste: "Há de voltar sempre a manhã? Nunca se termina o poder da Terra?". No entanto, "fora do tempo e do espaço está o domínio da noite."11. Ainda que trabalhando no regime noturno, o discurso arrisca-se, não capitula ao sono sem fim, pois opõe a tanta vacuidade o som mortal, a palavra acordada, a palavra-"tiro-nas-lebres-de-vidro-doinvisível" (CABRAL, 2008, p. 71) e nisso arrisca forma - brotação incessante - no real amorfo ,arredio, invisível, subitamente visualizável pela força imaginante (a Einbildungskraft, imaginação) da lírica . Pois "O que aparece na noite é a noite que aparece, e a estranheza não provém somente de algo invisível que se faria ver ao abrigo e a pedido das trevas: o invisível é então o que não se pode deixar de ver, o incessante que se faz ver." (BLANCHOT, 2011, p.177). O que dessa visibilidade nasce se lê ainda no mesmo poema:

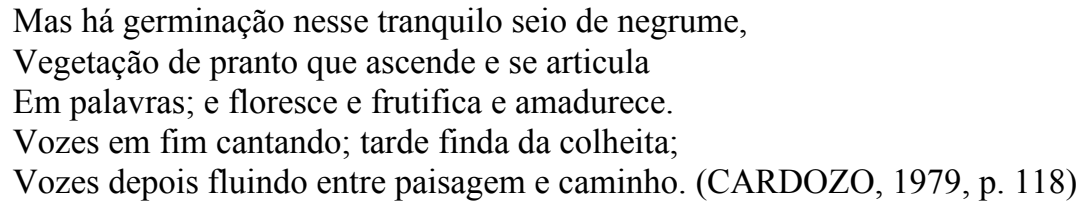

Olhando aqui as paisagens da poesia de Joaquim Cardozo, não há dúvida de que elas são zonas de turbulências, onde os ventos atuam como protagonistas assíduos, e onde se assiste também à "primazia do mar alto", tanto este ocupa a atenção da voz lírica, com suas ondas e os fantasmas trazidos sobretudo pela memória da terra nordestina dos Seiscentos, como as "(..) sombras dos melhores heróis de Pernambuco antigo" (CARDOZO, 1979, p. 23). E, claro, as outras águas, muitas águas - dos mangues, das chuvas, dos rios e das que passam sob inúmeras pontes ditas "apertos de mãos/ Que transportam de um lado para outro lado"; ou se apresentam como impeditivas do livre curso dos rios, que, por isso mesmo, delas se vingam: "Os rios às vezes se revoltam/ Reúnem todas as suas águas/ E investem sobre as pontesalgemas" (CARDOZO, 1979, p. 182). Poética, pois, do movimento, do fluxo incessante. E há ainda, lembremo-nos, a muito alastrada presença das sombras, desde as "sombras inocentes" de "Cajueiros de setembro" até as "sombras inimigas" de "Luzia, acende a lâmpada da sala", e sua inflexão existencial em "Sou um homem manchado de sombra" do "Canto do homem marcado" (CARDOZO, 1979, p. 77). O valor mais assinalável da sombra, porém, consiste no velamento por ela proporcionado, ao favorecer a imbricação dos seres, fenômeno que se vê iconicamente representado na grafia do próprio vocábulo na parte VIII da "Visão do último trem subindo ao céu", em que cada grafema se inclui nos que lhe são adjacentes.

\footnotetext{
${ }^{11}$ NOVALIS (2016, n.p.). O texto original diz: "Muss immer der Morgen wiederkommen? Endet nie des Irdischen Gewalt?" e "zeitlos und raumlos ist der Nacht Herrschaft".
}

Gláuks: Revista de Letras e Artes - jul./ dez. 2019 - Vol 19, $N^{o}$ 2, ISSN 2318-7131 
Assim como as sombras ensejam que as bordas delimitadoras e privativas dos entes se atenuem ou se desvaneçam, a noite promove na obra de Cardoso a corrosão gnosiológica. Certo, ela muitas vezes figura sob aspectos benfazejos, como a noite perfumada de "Cajueiros de setembro", a capaz de carícias de "Recife de outubro", a que é suave em "Poesia da presença invisível" ou a noite mansa, de "Poema do amor sem exagero". Mas sua presença maior dá-se pela capacidade de revelar "a pré-coisa fantasmática" (POZZI, 2015, n.p.), o ante-ser, como se lê em "Os objetos antes da noite":

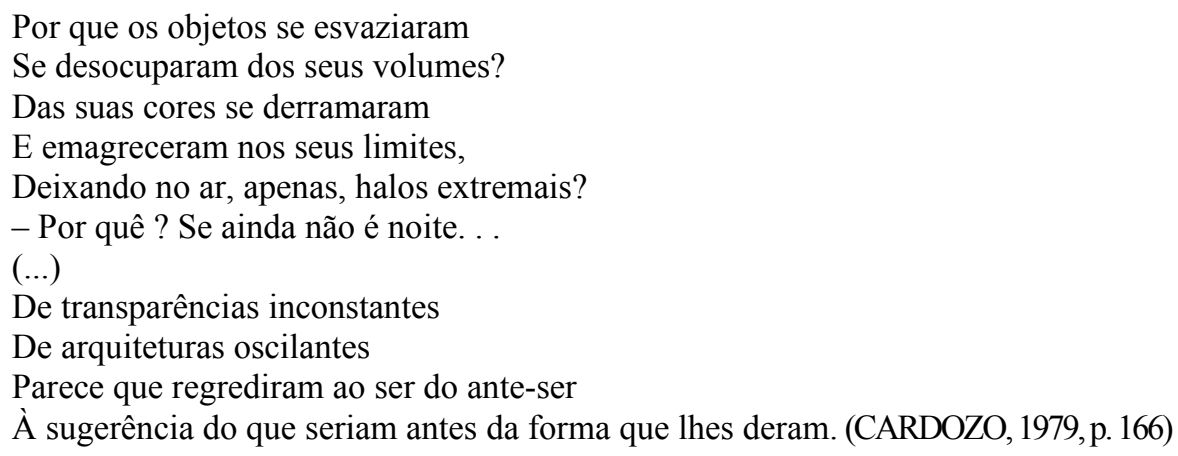

$\mathrm{Na}$ realidade, a fraturação da integridade do ser, o descortino do pré-ser atingem ocorrência apical em várias passagens da "Visão do último trem subindo céu", ao destituir o visível de suas conexões rotineiras, já que "O que aparece é o que parece" (CARDOZO, 1979, p.166). Esse modo de olhar abre caminho para composições heteróclitas, apagando a retração solipsista dos entes, integrandoos na unidade que de alguma maneira os sinonimiza para que possam coparticipar, como invenção e jogo (coup de dés) da aventura do sentido. Neste gesto de superação da mera parecença, do entediante engessamento da usança, a poesia de Cardozo não busca abolir o acaso, defenestrá-lo. Mas se trata, antes, de aceitar, no seio do anoitecido, a fenomenalização da latência, para que algum visível se "caleidoscopize" nessa noite, por pressão da "evenementialité pure du manteau anhistorique de la nuit" ${ }^{12}$. Quebra, pois, de lindes territoriais, esfacelamento da residência privativa dos entes, expansão de rearranjos, abertura ao potencial, integração em unidade plurívoca dos seres petrificados em designações excludentes. É o que se lê em "Canto da Serra dos Órgãos":

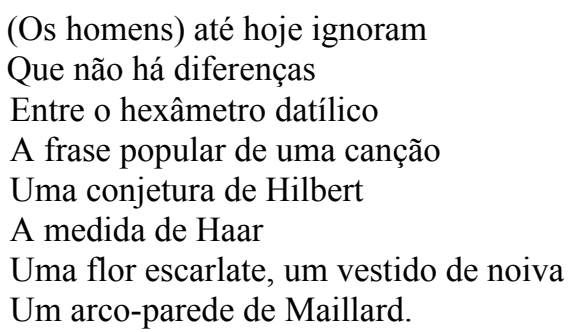

\footnotetext{
12 "Irrupção pura do manto a-histórico da noite" (traduzimos). Optamos, aqui, por irrupção na falta de vocábulo mais adequado (eventação, evenemencialidade, acontecimentalidade). Eventualidade não seria boa alternativa. Eventness, do inglês, parece mais adequado.
}

Gláuks: Revista de Letras e Artes - jul./ dez. 2019 - Vol 19, $N^{o}$ 2, ISSN 2318-7131 
As sombras e a noite propiciam, assim, o arremeter-se do sujeito e dos objetos ao baudelairiano "trouver du nouveau": "É preciso partir enquanto é noite,/Enquanto é aspiração de absoluto." diz-nos o "Prelúdio e elegia de uma despedida". Tal aspiração integra a ética/estética da aventura, que rasura roteiros prévios e nas quais a percepção está apta a suspender a imago do mundo imobilizado por designações e predicações exauridas, em proveito da leveza e da mobilidade, sobretudo se os ob-jetos puderem desgarrar-se de seu intransitivo autopertencimento e sua coesão utilitária, ou de sua previsível inserção discursiva, para uma visita ao infrequente, ao "enlouquecido", como resulta claro - ou favoravelmente obscuro (Noitemente amanhecer"13) - em "Os objetos antes da noite" em referência a estes últimos:

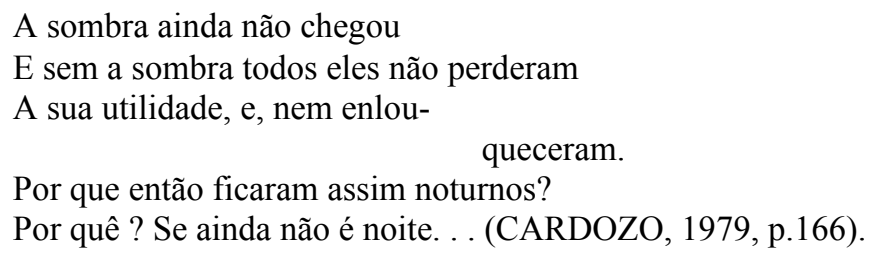

Em Cardozo há o empenho, tão da essência do lirismo, em angular os cômodos do visível de forma que se lhes tornem incômodos seus (i)móveis já muito decorados. Como observa Didi-Hubermann: "O ato de ver não é o ato de uma máquina de perceber o real enquanto composto de evidências tautológicas. $\mathrm{O}$ ato de dar a ver não é o ato de dar evidência visível a pares de olhos (...). Dar a ver é sempre inquietar o ver." (DIDI-HUBERMAN, 2010, p. 77). Por esse fundamento, a experiência de escavação da poesia de Joaquim Cardozo favorece sintagmas que constituem, por assim dizer, ousadias predicativas e nomeação atípica, o que parece radicalizar-se nos poemas de Trivium, ensejando disjunções esdrúxulas, ou linhas desenhadas que conglobam palavras e fragmentos de palavras em modulações discursivas díspares, de campos normalmente refratários à convivência do discurso poético e o da ciência, ensejando o estranhamento que se experimenta com terminologia nova ou a ressignificação de palavras à Heidegger, cujas expressões poderiam ser (des)entendidas "como trocadilho ou dadaísmo, mas também como uma tentativa de introduzir uma nova e diferente maneira de pensar, um "estado diferente" (KÖNIG, 2014, p. 118), pois "O estilo estranho de linguagem de Heidegger também decorre do fato de ele querer dizer algo que não pode ser dito com nossa conceitualidade (Begrifflichkeit)" (KÖNIG, 2012, n. p.).

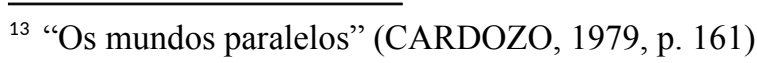

Gláuks: Revista de Letras e Artes - jul./ dez. 2019 - Vol 19, $N^{o} 2$, ISSN 2318-7131 


\title{
A paisagem, vista de longe
}

Neste sumário recenseamento de ventos, mares, sombras, rios etc. nas paisagens de Cardozo, o decisivo não deverá ter sido o restrito repertório das ocorrências, mas, tomando-as como exemplares, o lhes haver enfatizado a possível originalidade, pelo lugar relativo de cada uma delas, sua valência imaginária e imagética no conjunto das Poesias completas. Na simples alusão a uma varanda, como em "As varandas se alongam/ Num gesto atento e imóvel de quem espreita/ Rumor (...)" (CARDOZO, 1979, p. 4), toda a dicção mostra a varanda para que ela não seja mera varanda, confinada à sua eterna varandice. Obrigou-a o eu lírico a sair de seu apaziguado destino e a avarandar-se a um além de si, um além de sua melancólica fixidez, isto é, levou-a a ser, ainda na sua condição varanda, à feição dos que a ocupam, incorporando-lhes o ser, para que o ser da varanda revelasse também o ser na varanda. Daí esse alongamento, com que certa predisposição do olhar poético a fitou e fixou, retirando-a de seu esgotado destino.

É que a incidência quantitativa de algum elemento, na análise/interpretação do texto literário, só faz sentido se submetida ao exame da posição desse elemento no todo do texto. $\mathrm{O}$ essencial é, portanto, ver na paisagem o modo como a paisagem é vista; em última análise, é ver o ver. Ou, como observa Collot:

\begin{abstract}
"A paisagem não é a região, mas certa maneira de vê-la ou de figurá-la como "conjunto" perceptiva ou esteticamente organizado: ela jamais se encontra in situ, mas sempre também in visu e/ou in arte. Sua realidade é perceptível apenas através de uma percepção e/ou de uma representação. Portanto, para compreender ou apreciar uma paisagem artística ou literária, importa menos compará-la a seu referente eventual (uma "extensão de região") do que considerar a maneira como é abarcada e expressa. (COLLOT, 2013, p. 50).
\end{abstract}

Deixemos, pois, os últimos vestígios das paisagens de Cardozo nesta consideração de uma poesia tantas vezes visitada pelo fascínio dos andaimes algo invisíveis do visível. O que, na materialidade do texto poético, torna-se igualmente os andaimes visíveis do invisível. Habita esse olhar certa "impressionante transversalidade" do impulso novalisiano ${ }^{14}$. Espécie de arquitetura do sub- e do sobreterrâneo, poética do entre-visto e do entre-haver, animada de expressivas prosopopeias, de rearranjos de demarcações ônticas, mobilizados pelo "sonho: gás da razão fíctícia"15, a poesia de Cardozo, como na imagem do aeroporto em Manuel Bandeira, dá-nos constantes "lições de partir". Mas partir não como experiência da morte concreta, mas da mais simbólica, penosamente rica, com a qual o vislumbre do sentido-outro se possa discernir.

\footnotetext{
${ }^{14}$ DUMONT, J. (2011, p. 624).

${ }^{15}$ CARDOZO (1979, p. 145).
}

Gláuks: Revista de Letras e Artes - jul./ dez. 2019 - Vol 19, $N^{o} 2$, ISSN 2318-7131 
Experiência histórica e transhistórica, portanto. Porém, na dialética de superação do enraizamento na paisagem, a vocação de transpor - talvez a marca mais eloquente do fascínio pelo mundo-a-mover-se na poesia de Joaquim Cardozo - não abandona a memória da fonte, antes expande a proveniência da "terra plantada, de muita imaginação" do poeta. Terra, como vimos, de noites de muito mar - a "primazia do mar alto" - e de ventos, muitos ventos. Atentando, pois, nestes ventos, que das terras cardozianas partiram e agora já nos tocam, na derradeira lembrança das paisagens que atravessamos; e dis-traindo-nos, mas não de todo, da sábia lição de mestre Caeiro de que "o vento só fala do vento", a obra de Cardozo deixa-nos ouvir, pela escuta dos poemas, os ventos a falarem dos ventos.

\section{Referências Bibliográficas}

ABRAMS, M. H., The fourth dimension of a poem. N. York, London: Norton \& Company, 2012.

BILAC, Olavo. Poesias. Belo Horizonte: Itatiaia, 1985.

BLANCHOT, Maurice. O espaço literário. Rio de Janeiro, Rocco, 2011.

CARDOZO, Joaquim. Poesias completas. 2.ed. Rio de Janeiro: Civilização Brasileira, 1979.

COLLOT, Michel. Poética e filosofia da paisagem. Rio de Janeiro: Oficina Raquel, 2013.

COQUET, Jean-Claude. A busca do sentido. São Paulo, Martins Fontes, 2013.

DUMONT, Augustin. Angoisse et extase de l'image transcendantale dans les Hymnes à la nuit, ou Shakespeare à l'épreuve de Novalis. In: Études germaniques, v. 66. Paris: Klincksieck, 2011.

DIDI-HUBERMAN, Georges. O que vemos, o que nos olha. 2.ed. São Paulo: Editora 34, 2010.

KÖNIG, Siegfried. Martin Heidegger. Sein Leben und seine Werke. Edição Kindle, 2014. . Martin Heideggers "Sein und Zeit”. Eine Einführung. Edição Kindle, 2012.

LEOPARDI, Giacomo. Canti. Milano: Rizzoli, 1974.

NOVALIS, Friedrich von Hardenberg. Hymnen an die Nacht. In: . Gesammelte

Werke. Braunschweig: Ideenbrücke, 2016.

MELO NETO, João Cabral. 2.ed. Poesia completa e prosa. Org. Antonio Carlos Secchin. Rio de Janeiro: Nova Aguilar, 2008. 
POZZI, Enrico. Appunti per la lettura di Merleau-Ponty. Italia: Matrioska Edizioni, 2015.

VARELA, Fagundes. Poesias completas. 2.ed. São Paulo: Saraiva, 1962.

\section{Quelques aspects du paysage chez joaquim cardozo}

Résumé: Cet article a pour but d'examiner certaines composantes, telles que les ombres, la nuit, les vents et la mer dans la poésie de Joaquim Cardozo, en essayant de comprendre comment le sujet lyrique les articule, la dialectique entre le fonds historique et la vocation de dépasser cet enracinement, les supports stylistiques dont se sert le poète et l'expression de la présence du monde que ses poèmes manifestent.

Mots-clés: Joaquim Cardozo. Poésie et paysage. 